\title{
HUBUNGAN PENGETAHUAN PERAWAT TENTANG INFEKSI NOSOKOMIAL DENGAN TINDAKAN PENCEGAHANNYA PADA PASIEN PASCABEDAH DI RUANG RAWAT INAP RUMAH SAKIT IMELDA MEDAN
}

\author{
Hamonangan Damanik \\ Dosen Prodi S1Keperawatan, STIKes Imelda, Jalan Bilal Nomor 52 Medan
}

Email: hamonangandamanik1112@gmail.com

\begin{abstract}
ABSTRAK
Infeksi nosokomial merupakan infeksi pada waktu penderita dirawat di rumah sakit tidak sedang dalam masa inkubasi dari infeksi tersebut, yang terjadi karena adanya interaksi antara host, agent, dan environment. Pengetahuan atau kognitif merupakan domain yang sangat penting dalam membentuk tindakan seseorang. Tujuan penelitian ini adalah untuk mengetahui hubungan pengetahuan perawat tentang infeksi nosokomial dengan tindakan pencegahannya pada pasien pascabedah di ruang rawat inap Rumah Sakit Imelda Medan 2017. Jenis penelitian deskriptif korelasi, pengambilan sampel dilakukan dengan cara total sampling dengan jumlah 31 orang perawat, dan pengambilan data dikumpulkan dengan menggunakan kuesioner. Hasil penelitian mengenai pengetahuan perawat tentang infeksi nosokomial mayoritas berpengetahuan sedang yaitu sebanyak 20 orang (64,5\%), sedangkan untuk tindakan pencegahannya mayoritas baik yaitu sebanyak 19 orang (61,3\%). Hasil penelitian yang dilakukan dengan menggunakan uji Rank Spearman untuk melihat hubungan pengetahuan perawat tentang infeksi nosokomial dengan tindakan pencegahannya pada pasien pascabedah maka diperoleh hasil dengan nilai probabilitas $(p)=0,011(p<0,05)$ yang artinya ada hubungan dengan kekuatan hubungan $(r)=0,452$, berarti kekuatan hubungannya cukup dan hubungan ini bersifat positif yang artinya jika pengetahuan perawat tentang infeksi nosokomial cukup maka makin cukup nilai tindakan pencegahan infeksi yang diperoleh.
\end{abstract}

Kata kunci $\quad$ : Pengetahuan, Infeksi Nosokomial, Tindakan Pencegahan.

\section{PENDAHULUAN}

Klien dalam lingkungan perawatan kesehatan beresiko terkena infeksi karena daya tahan yang menurun terhadap mikroorganisme infeksius, meningkatnya pajanan terhadap jumlah dan jenis penyakit yang disebabkan oleh mikroorganisme dan prosedur invasif. Dengan cara mempraktikka $\mathrm{n}$ teknik pencegahan dan pengendalian infeksi, perawat dapat menghindarkan penyebaran mikroorganisme terhadap klien (Potter \& Perry, 2005).

Pengetahuan tentang pencegahan infeksi sangat penting untuk petugas rumah sakit dan sarana kesehatan lainnya merupakan sarana umum yang sangat berbahaya, dalam artian rawan untuk terjadi infeksi. Kemampuan untuk mencegah transmisi infeksi di rumah sakit dan upaya pencegahan infeksi adalah tingkatan pertama dalam pemberian pelayanan yang bermutu (Martono, 2003).
Walaupun penyebaran penyakit infeksi dirumah sakit telah dikenal sejak lama, pemahaman bagaimana mencegah infeksi nosokomial (yang didapat di rumah sakit) dan implementasi secara baik masih sulit. Penularan infeksi nosokomial memerlukan 3 unsur, yaitu sumber mikroorganisme, sasaran yang sensitif, dan cara penularan (Tietjen, 2004).

Infeksi nosokomial bisa bersumber dari petugas kesehatan, pasien yang lain, alat dan bahan yang digunakan untuk pengobatan maupun dari lingkungan rumah sakit. Faktorfaktor yang mempengaruhi terjadinya infeksi nosokomial antara lain : faktor internal (seperti usia, penggunaan obat, penyakit penyerta, malnutrisi, kolonisasi flora normal tubuh, personal hygiene yang rendah, perilaku personal dan lain-lain) serta faktor eksternal (seperti banyaknya petugas kesehatan yang kontak langsung dengan pasien, banyaknya prosedur invasif, lama ting 
gal di RS, lingkungan yang terkontaminasi dan lain-lain) (Purwanto, 2007 ).

Infeksi nosokomial merupakan suatu masalah yang nyata di seluruh dunia dan terus meningkat. Suatu survey prevalensi meliputi 55 rumah sakit di 14 negara berkembang pada 4 wilayah World Health Organization (WHO) (Eropa, Mediterania Timur, Asia Tenggara, dan Pasifik Barat) menemukan rata-rata $8,7 \%$ dari seluruh pasien rumah sakit menderita infeksi nosokomial. Jadi, setiap saat terdapat 1,4 juta pasien di seluruh dunia terkena komplikasi infeksi yang didapat di rumah sakit. Penelitian WHO dan lain-lain, juga menemukan bahwa prevalensi infeksi nosokomial yang tertinggi terjadi di intensive care unit (ICU), perawatan bedah akut, dan bangsal ortopedi (Tietjen, 2004).

Hasil survey di Unaited State American (USA) yang mengidentifikasikan bahwa infeksi nosokomial terjadi sekitar 5\% penderita akut yang dirawat dirumah sakit dan $8 \%$ pada penderita yang kronis. Insiden infeksi nosokomial, lebih tinggi pada klien bedah, infeksi nosokomial pada klien post operasi 70\% (Iwan, 2007).

Hasil penelitian di Rumah Sakit Umum Daerah Kepanjen dengan sampel 120 perawat untuk melihat hubungan pengetahuan perawat tentang infeksi nosokomial dan pencegahannya dengan angka prevalensi infeksi nosokomial di RS tersebut memperlihatkan hasil ada hubungan yang kuat dengan indeks korelasi 0,6. Dari penelitian tersebut disimpulkan bahwa peran perawat dalam pengontrolan infeksi nosokomial perlu dioptimalisasi (Martono, 2003).

Salah satu strategi yang sudah terbukti bermanfaat dalam pengendalian infeksi nosokomial adalah peningkatan kemampuan petugas kesehatan dalam metode Universal Precautions atau dalam bahasa Indonesia Kewaspadaan Universal (KU) yaitu suatu cara penanganan baru untuk meminimalkan pajanan darah dan cairan tubuh dari semua pasien, tanpa memperdulikan status infeksi. Dasar KU adalah cuci tangan secara benar, penggunaan alat pelindung, desinfeksi dan mencegah tusukan alat tajam, dalam upaya mencegah transmisi mikroorganisme melalui darah dan cairan tubuh (Sulianti, 2007).

\section{Rumusan Masalah}

Apakah ada hubungan pengetahuan perawat tentang infeksi nosokomial dengan tindakan pencegahannya pada pasien pasca bedah di ruang rawat inap Rumah Sakit Imelda Medan.

\section{Tujuan Penelitian}

Untuk mengetahui dan menjelaskan sejauh mana hubungan pengetahuan perawat tentang infeksi nosokomial dengan tindakan pencegahannya pada pasien pascabedah di ruang rawat inap Rumah Sakit Imelda.

\section{METODE}

\section{Jenis dan Desain Penelitian}

Dalam penelitian ini menggunakan jenis penelitian deskriptif korelasi yang bertujuan untuk mengetahui dan menjelaskan sejauh mana hubungan pengetahuan perawat tentang infeksi nosokomial dengan tindakan pencegahannya pada pasien pascabedah di ruang rawat inap Rumah Sakit Imelda.

\section{Tempat dan Waktu Penelitian}

Tempat penelitian adalah Rumah Sakit Imelda. Penelitian ini dilakukan pada bulan Mei 2017.

\section{Populasi dan Sampel}

Populasi dalam penelitian ini adalah seluruh tenaga perawat di ruang rawat inap Rumah Sakit Imelda sebanyak 205 orang. Sampel adalah pasien hemodialisis, pengambilan sampel penelitian dilakukan dengan tekhnik Nonprobability sampling yaitu Purposive Sampling. Disini peneliti menggunakan rumus Surakhmat (1981) menyatakan bahwa apabila populasi lebih dari 200, maka besar sampel dapat diambil antara $15-20 \%$, sehubungan dengan populasi penelitian sebesar 205 orang maka besar sampel diambil $15 \%$.

$$
\begin{aligned}
\mathrm{n} & =\mathrm{N} \times 15 \% \\
& =205 \times 15 \% \\
& =30,75
\end{aligned}
$$


Jadi sampel yang diambil sebanyak 31 orang dan yang memenuhi kriteria sebagai berikut :

1. Pasien yang sudah menjalani hemodialis is lebih dari 2 (dua) kali.

2. Dapat menulis, membaca dan berkomuni kasi dengan bahasa Indonesia.

3. Bersedia menjadi responden.

\section{Aspek Pengukuran}

Dalam mengukur hubungan pengetahuan perawat tentang infeksi nosokomial dengan tindakan pencegahan infeksi nosokomial pada pasien pascabedah di ruang rawat inap, diberikan kuesioner sebanyak 40 pertanyaan. Kuesioner pengukuran pengetahu an perawat menggunakan multiple choice dengan jumlah soal 20, menyediakan beberapa jawaban / alternative jika jawaban benar dengan skor 1 dan jika salah dengan skor 0 . Pengukuran tindakan pencegahan infeksi menggunakan dicotomi dengan jumlah soal 20, menyediakan alternative jawaban ya dengan skor 1 , tidak dengan skor 0.

\section{Teknik Pengumpulan Data}

Metode pengumpulan data dilakukan dengan cara menyebarkan kuisioner yang telah disiapkan. Responden yang bersedia diminta untuk menandatangani lembar persetujuan yang telah disediakan. Dalam melakukan analisa data, peneliti mengikuti prosedur dan langkah-langkah analisa, sebagai berikut : Editing, Coding, Entry, Tabulating.

\section{Metode Analisa Data}

a. Analisa Univariat

Yaitu untuk mengetahui distribusi frekuensi, dan persentase dari masingmasing variabel bebas dan variabel terikat.

b. Analisa Bivariat

Yaitu untuk mengetahui hubungan antara variabel bebas dan terikat dengan menggunakan uju statistik Rank Spearman.
HASIL

Dari hasil penelitian yang dilakukan pada 31 orang responden didapat bahwa kelompok umur perawat yang berada di Rumah Sakit Imelda Medan 2017 dapat dilihat pada tabel distribusi berikut ini :

Tabel 1.Distribusi Frekuensi Berdasarkan Umur Perawat Di RS Imelda Medan

\begin{tabular}{cccc}
\hline No & Umur & Jumlah & $\begin{array}{c}\text { Persentase } \\
(\mathbf{\%})\end{array}$ \\
\hline 1. & 22-33 Tahun & 11 & 35,5 \\
\hline 2. & $34-45$ Tahun & 14 & 45,2 \\
\hline 3. & 46-56 Tahun & 6 & 19,4 \\
\hline & Total & $\mathbf{3 1}$ & $\mathbf{1 0 0}$ \\
\hline
\end{tabular}

Berdasarkan tabel 1 diatas dapat diketahui bahwa mayoritas kelompok umur perawat 34 samapi 45 tahun yaitu sebanyak 14 orang $(45,2 \%)$.

Tabel 2. Distribusi Frekuensi Berdasarkan Jenis Kelamin Perawat Di RS Imelda Kota Medan

\begin{tabular}{cc|cc}
\hline No & $\begin{array}{c}\text { Jenis Kelamin } \\
\text { Perawat }\end{array}$ & Jumlah & $\begin{array}{c}\text { Persentase } \\
(\mathbf{\%})\end{array}$ \\
\hline 1. & Laki-laki & 3 & 9,7 \\
\hline 2. & Perempuan & 28 & 90,3 \\
\hline & Total & $\mathbf{3 1}$ & $\mathbf{1 0 0}$ \\
\hline
\end{tabular}

Berdasrkan table 2 diatas dapat diketahui bahwa kelompok jenis kelamin perawat mayoritas berjenis kelamin perempuan yaitu 28 orang $(90,3 \%)$ sedangkan perawat lakilaki hanya 3 orang $(9,7 \%)$

Tabel 3. Distribusi Frekuensi Berdasarkan Pendidikan Perawat Di RS Imelda Kota Medan

\begin{tabular}{cccc}
\hline No & $\begin{array}{c}\text { Pendidikan } \\
\text { Perawat }\end{array}$ & Jumlah & $\begin{array}{c}\text { Persentase } \\
(\mathbf{\%})\end{array}$ \\
\hline 1. & SPK & 6 & 16,1 \\
\hline 2. & DIII & 24 & 77,4 \\
\hline 3. & S-1 & 2 & 6,5 \\
\hline & Total & $\mathbf{3 1}$ & $\mathbf{1 0 0}$ \\
\hline
\end{tabular}

Berdasarkan tabel 3 diatas dapat diketahui bahwa kelompok pendidikan perawat mayoritas DIII keperawatan yaitu 24 orang $(77,4 \%)$, SPK sebanyak 5 orang $(16,1 \%)$ dan S-1 Keperawatan sebanyak 2 orang $(6,5 \%)$. 
Tabel 4. Distribusi Frekuensi Berdasarkan Lama Kerja Perawat Di RS Imelda Kota Medan

\begin{tabular}{cccc}
\hline No & $\begin{array}{c}\text { Lama Kerja } \\
\text { Perawat }\end{array}$ & Jumlah & $\begin{array}{c}\text { Persentase } \\
(\mathbf{\%})\end{array}$ \\
\hline 1. & $2-10$ Tahun & 11 & 35,5 \\
\hline 2. & $11-19$ Tahun & 4 & 12,9 \\
\hline 3. & $20-28$ Tahun & 16 & 51,6 \\
\hline & Total & $\mathbf{3 1}$ & $\mathbf{1 0 0}$ \\
\hline
\end{tabular}

Berdasarkan tabel 4 diatas dapat diketahui bahwa lama kerja perawat mayoritas adalah dalam rentang waktu 20-28 tahun sebanyak 16 orang $(51,6 \%)$.

Tabel 5. Distribusi Frekuensi Berdasarkan Pengetahuan Perawat Tentang Pengertian Infeksi Nosokomial Di RS Imelda Kota Medan

\begin{tabular}{|c|c|c|c|}
\hline No. & $\begin{array}{l}\text { Pengetahuan } \\
\text { Tentang } \\
\text { Pengertian } \\
\text { Infeksi } \\
\text { Nosokomial }\end{array}$ & Jumlah & $\begin{array}{c}\text { Persentasi } \\
(\%)\end{array}$ \\
\hline 1. & Rendah & 15 & 48,4 \\
\hline 2. & Sedang & 13 & 41,9 \\
\hline 3. & Baik & 3 & 9,7 \\
\hline & Total & 31 & 100 \\
\hline
\end{tabular}

Berdasarkan tabel 5 diatas dapat diketahui bahwa mayoritas pengetahuan perawat tentang pengertian infeksi nosokomial yaitu rendah sebanyak 15 orang $(48,4 \%)$. Dari data dapat dijelaskan bahwa karakteristik pengetahuan perawat tentang pengertian infeksi nosokomial berkategori rendah yaitu 15 orang.

Tabel 6. Distribusi Frekuensi Berdasarkan Pengetahuan Perawat Tentang Jenis-jenis Infeksi Nosokomial Di RS Imelda Kota Medan

\begin{tabular}{cccc}
\hline No. & $\begin{array}{c}\text { Pengetahuan } \\
\text { Tentang } \\
\text { Jenis-jenis } \\
\text { Infeksi } \\
\text { Nosokomial }\end{array}$ & Jumlah & $\begin{array}{c}\text { Persentasi } \\
(\%)\end{array}$ \\
\hline 1. & Rendah & 4 & 12,9 \\
\hline 2. & Sedang & 18 & 58,1 \\
\hline 3. & Baik & 9 & 29 \\
\hline \multicolumn{6}{c}{ Total } & $\mathbf{3 1}$ & $\mathbf{1 0 0}$ \\
\hline Berdasarkan tabel 6 & diatas dapat \\
diketahui & bahwa & mayoritas & pengetahuan
\end{tabular}

perawat tentang jenis-jenis infeksi nosokomial yaitu sedang sebanyak 18 orang $(58,1 \%)$. Dari data di atas menunjukkan bahwa karakteristik pengetahuan perawat tentang jenis-jenis infeksi nosokomial berkategori sedang yaitu 18 orang.

Tabel 7. Distribusi Frekuensi Berdasarkan Pengetahuan Perawat Tentang Faktor-faktor Terjadinya Infeksi Nosokomial Di RS Imelda Kota Medan

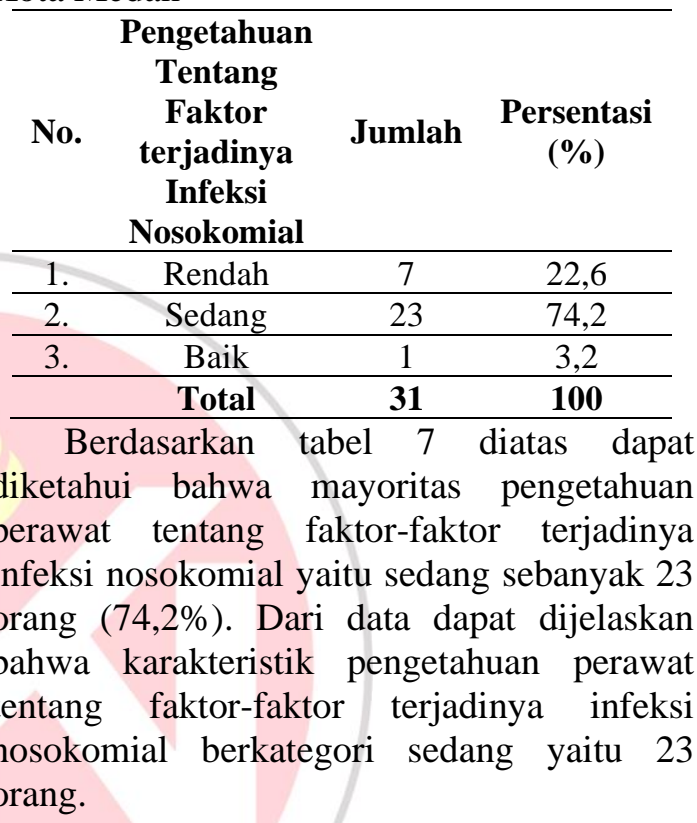

Tabel 8. Distribusi Frekuensi Berdasarkan Pengetahuan Perawat Tentang Pertahanan Terhadap Infeksi Nosokomial Di RS Imelda Kota Medan

\begin{tabular}{|c|c|c|c|}
\hline No. & $\begin{array}{l}\text { Pengetahuan } \\
\text { Tentang } \\
\text { Pertahanan } \\
\text { Terhadap } \\
\text { Infeksi } \\
\text { Nosokomial }\end{array}$ & Jumlah & $\begin{array}{c}\text { Persentasi } \\
(\%)\end{array}$ \\
\hline 1. & Sedang & 9 & 29 \\
\hline \multirow[t]{2}{*}{2.} & Baik & 22 & 71 \\
\hline & Total & 31 & 100 \\
\hline
\end{tabular}

Berdasarkan tabel 8 diatas dapat diketahui bahwa mayoritas pengetahuan perawat tentang pertahanan terhadap infeksi nosokomial yaitu baik sebanyak 22 orang (71\%). Dari data dapat dijelaskan bahwa karakteristik pengetahuan perawat tentang pertahanan terhadap infeksi nosokomial berkategori baik sebanyak 22 orang. 
Tabel 9. Distribusi Frekuensi Berdasarkan Pengetahuan Perawat Tentang Gejala Infeksi Nosokomial Di RS Imelda Kota Medan

\begin{tabular}{|c|c|c|c|}
\hline No. & $\begin{array}{c}\text { Pengetahuan } \\
\text { Tentang } \\
\text { GejalaInfeksi } \\
\text { Nosokomial }\end{array}$ & Jumlah & $\begin{array}{c}\text { Persentasi } \\
(\%)\end{array}$ \\
\hline 1. & Sedang & 19 & 61,3 \\
\hline \multirow[t]{2}{*}{2.} & Baik & 12 & 38,7 \\
\hline & Total & 31 & 100 \\
\hline
\end{tabular}

Berdasarkan tabel 9 diatas dapat diketahui bahwa mayoritas pengetahuan perawat tentang gejala infeksi nosokomial yaitu sedang sebanyak 19 orang $(61,3 \%)$. Dari data dapat dijelaskan bahwa karakteristik pengetahuan perawat tentang gejala infeksi nosokomial dikategorikan sedang sebanyak 19 orang.

Tabel 10. Distribusi Frekuensi Berdasarkan Pengetahuan Perawat Tentang Infeksi Nosokomial Di RS Imelda Kota Medan

\begin{tabular}{cccc}
\hline No. & $\begin{array}{c}\text { Pengetahuan } \\
\text { Perawat } \\
\text { tentang } \\
\text { Infeksi } \\
\text { Nosokomial }\end{array}$ & Jumlah & $\begin{array}{c}\text { Persentase } \\
(\mathbf{\%})\end{array}$ \\
\hline 1. & Sedang & 20 & 64,5 \\
\hline 2. & Baik & 11 & 35,5 \\
\hline & Total & $\mathbf{3 1}$ & $\mathbf{1 0 0}$ \\
\hline
\end{tabular}

Berdasarkan tabel 4.10 diatas dapat diketahui bahwa mayoritas pengetahuan perawat tentang infeksi nosokomial yaitu sedang sebanyak 20 orang $(64,5 \%)$. Dari data dapat dijelaskan bahwa karakteristik pengetahuan perawat tentang infeksi nosokomial belum dapat dikategorikan baik tetapi berdasarkan tabel diatas masih dianggap sedang sebanyak 20 orang.

Tabel 11. Distribusi Frekuensi Berdasarkan Tindakan Pencegahan Infeksi Nosokomial Di RS Imelda Kota Medan

\begin{tabular}{|c|c|c|c|}
\hline No. & $\begin{array}{c}\text { Tindakan } \\
\text { Pencegahan } \\
\text { Infeksi } \\
\text { Nosokomial }\end{array}$ & Jumlah & $\begin{array}{c}\text { Persentasi } \\
(\%)\end{array}$ \\
\hline 1. & Buruk & 2 & 6,5 \\
\hline 2. & Sedang & 10 & 32,3 \\
\hline 3. & Baik & 19 & 61,3 \\
\hline & Total & 31 & 100 \\
\hline
\end{tabular}

Berdasarkan tabel 11 diatas dapat diketahui bahwa mayoritas tindakan pencegahan infeksi nosokomial yaitu baik sebanyak 19 orang $(61,3 \%)$. Dari data dapat dijelaskan bahwa karakteristik tindakan perawat dalam pencegahan infeksi nosokomial dikategorikan baik sebanyak 19 orang.

Tabel 12. Tabulasi Silang Berdasarkan Pengetahuan Perawat Tentang Infeksi Nosokomial Dengan Tindakan Pencegahannya Di RS Imelda Kota Medan

\begin{tabular}{|c|c|c|c|c|c|c|c|c|c|}
\hline \multirow{3}{*}{ No } & \multirow{3}{*}{$\begin{array}{c}\text { Pengetahuan Perawat } \\
\text { Tentang Infeksi } \\
\text { Nosokomial }\end{array}$} & \multicolumn{6}{|c|}{$\begin{array}{c}\text { Tindakan Pencegahan Infeksi } \\
\text { Nosokomial }\end{array}$} & \multirow{2}{*}{\multicolumn{2}{|c|}{ Total }} \\
\hline & & \multicolumn{2}{|c|}{ Buruk } & \multicolumn{2}{|c|}{ Sedang } & \multicolumn{2}{|c|}{ Baik } & & \\
\hline & & $\mathbf{F}$ & $\%$ & $\mathbf{F}$ & $\%$ & $\mathbf{F}$ & $\%$ & $\mathbf{F}$ & $\%$ \\
\hline 1. & Sedang & 2 & 6,5 & 9 & 29,0 & 9 & 29,0 & 20 & 64,5 \\
\hline \multirow[t]{2}{*}{2.} & Baik & 0 & 0 & 1 & 3,2 & 10 & 32,3 & 11 & 35,5 \\
\hline & Total & 2 & 6,5 & 10 & 32,3 & 19 & 61,3 & 31 & 100 \\
\hline
\end{tabular}

Berdasarkan tabel 12 diatas dapat dilihat bahwa pengetahuan perawat tentang infeksi nosokomial sedang yaitu 20 orang $(64,5 \%)$ dengan tindakan pencegahan infeksi nosokomial baik dan sedang masing-masing 9 orang $(29,0 \%)$. Pengetahuan perawat tentang infeksi nosokomial baik yaitu 11 orang $(35,5 \%)$ dengan tindakan pencegahan infeksi nosokomial baik 10 orang $(32,3 \%)$. 
Tabel 13. Korelasi Pengetahuan Perawat tentang Infeksi Nosokomial dengan Tindakan Pencegahannya Di RS Imelda Kota Medan

\begin{tabular}{|c|c|c|c|c|}
\hline No. & Variabel & Spearman's rho & $\begin{array}{c}\text { Pengetahuan } \\
\text { Perawat tentang } \\
\text { Infeksi Nosokomial }\end{array}$ & $\begin{array}{c}\text { Tindakan } \\
\text { Pencegahan Infeksi } \\
\text { Nosokomial } \\
\end{array}$ \\
\hline 1. & $\begin{array}{l}\text { Pengetahuan Perawat } \\
\text { tentang Infeksi } \\
\text { Nosokomial }\end{array}$ & $\begin{array}{c}\text { Coefisien } \\
\text { Correlation } \\
\text { Sig (2-tailed) } \\
\mathrm{N} \\
\end{array}$ & $\begin{array}{c}1,000 \\
31\end{array}$ & $\begin{array}{c}, 452^{*} \\
, 011 \\
31\end{array}$ \\
\hline 2. & $\begin{array}{c}\text { Tindakan Pencegahan } \\
\text { Infeksi Nosokomial }\end{array}$ & $\begin{array}{c}\text { Coefisien } \\
\text { Correlation Sig } \\
\text { (2-tailed) } \\
\mathrm{N} \\
\end{array}$ & $\begin{array}{c}, 452 * \\
, 011 \\
31\end{array}$ & $\begin{array}{c}1,000 \\
31\end{array}$ \\
\hline
\end{tabular}

Berdasarkan tabel 13 diatas dapat dilihat bahwa hubungan pengetahuan perawat tentang infeksi nosokomial dengan tindakan pencegahan infeksi nosokomial dengan nilai probabilitas $(\mathrm{p})=0,011(\mathrm{p}<$ $0,05)$ berarti ada hubungan pengetahuan perawat tentang infeksi nosokomial dengan tindakan pencegahan infeksi nosokomial. Kekuatan hubungan $(r)=0,452$, berarti kekuatan hubungannya cukup.

\section{PEMBAHASAN}

Berdasarkan pengetahuan perawat tentang pengertian infeksi nosokomial mayoritas berkategori rendah yaitu sebanyak 15 orang $(48,4 \%)$, pengetahuan perawat tentang jenis-jenis infeksi nosokomial mayoritas berkategori sedang yaitu sebanyak 18 orang $(58,1 \%)$, pengetahuan perawat tentang faktor-faktor terjadinya infeksi nosokomial mayoritas berkategori sedang yaitu 23 orang $(74,2 \%)$, pengetahuan perawat tentang pertahanan terhadap infeksi nosokomial mayoritas berkategori baik sebanyak 22 orang (71\%), pengetahuan perawat tentang gejala infeksi nosokomial mayoritas berkategori sedang sebanyak 19 orang $(61,3 \%)$.

Berdasarkan pengetahuan perawat tentang infeksi nosokomial mayoritas berkategori sedang sebanyak 20 orang $(64,5 \%)$ dengan tindakan pencegahan baik dan sedang masing-masing sebanyak 9 orang $(29,0 \%)$ dan buruk 2 orang $(6,5 \%)$. Dari data dapat dijelaskan bahwa perawat yang berpengetahuan sedang mampu melakukan tindakan pencegahan infeksi dengan baik, hal ini dimungkinkan karena jika dilihat dari pengalaman bekerja perawat mayoritas telah bekerja selama 20-28 tahun, dari pengalaman ini perawat memperoleh banyak informasi mengenai tindakantindakan yang tepat dalam pencegahan infeksi nosokomial. Menurut Notoatmodjo (2003), yang menyatakan bahwa pengetahua $\mathrm{n}$ dipengaruhi oleh beberapa faktor yaitu umur, pendidikan, pekerjaan dan sumber informasi.

Hasil penelitian yang dilakukan dengan menggunakan uji Rank Spearman untuk melihat hubungan pengetahuan perawat tentang infeksi nosokomial dengan tindakan pencegahan infeksi nosokomial maka diperoleh hasil dengan nilai probabilitas (p) $=0,011(\mathrm{p}<0,05)$ yang artinya ada hubungan dengan kekuatan hubungan $(\mathrm{r})=$ 0,452 , berarti kekuatan hubungannya cukup dan hubungan ini bersifat positif yang artinya jika pengetahuan perawat tentang infeksi nosokomial cukup maka makin cukup nilai tindakan pencegahan infeksi yang diperoleh.

Hal ini dibuktikan oleh Notoatmodjo (2003), yang menyatakan pengetahuan atau kognitif merupakan domain yang sangat penting dalam membentuk tindakan seseorang (overt behavior). Dari hasil penelitian Ariani I Gusti Ayu Dewi (2000), mengenai studi tentang pengetahuan, sikap dan tindakan perawat dalam upaya pencegahan resiko tertular hepatitis B di RSUD Singaraja diperoleh sebagian besar (84\%) responden mempunyai kategori pengetahuan cukup, 90,6\% bersikap positif dan $82,8 \%$ melaksanakan tindakan dengan 
kategori cukup. Makin cukup pengetahuan dan sikap, makin cukup nilai tindakan yang diperoleh.

Berdasarkan hasil penelitian yang dilakukan oleh Indra Gunawan (2006) mengenai hubungan tingkat pengetahuan perawat tentang infeksi nosokomial post operatif appendik dengan cara perawatan di ruang rawat inap RSU Sari Mutiara Medan memperlihatkan hasil ada hubungan, ini dilihat dari metode penelitian dengan menggunakan uji statistik korelasi ProducMoment dengan nilai $(\mathrm{p})=0,002(\mathrm{p}<0,05)$ dengan kekuatan hubungan $(\mathrm{r})=0,544$.

Hasil penelitian di Rumah Sakit Umum Daerah Kepanjen dengan sampel 120 perawat untuk melihat hubungan pengetahua $\mathrm{n}$ perawat tentang infeksi nosokomial dan pencegahannya dengan angka prevalensi infeksi nosokomial di RS tersebut memperlihatkan hasil ada hubungan yang kuat dengan indeks korelasi 0,6. Dari penelitian tersebut disimpulkan bahwa peran perawat dalam pengontrolan infeksi nosokomial perlu dioptimalisasi (Martono, 2003).

Dari hasil penelitian yang dilakukan terlihat bahwa perawat yang berpengetahuan sedang tentang infeksi nosokomial mampu melakukan tindakan pencegahan dengan baik, hal ini dimungkinkan karena perawat tidak tahu bahwa tindakan yang dilakukannya baik.

\section{KESIMPULAN}

Berdasarkan hasil penelitian yang telah dilakukan di Rumah Sakit Umum Imelda Pekerja Indonesia Medan, maka diperoleh kesimpulan sebagai berikut:

1. Karakteristik responden berdasarkan pengetahuan perawat tentang pengertia

$\mathrm{n}$ infeksi nosokomial mayoritas berkategori rendah yaitu 15 orang $(48,4 \%)$.

2. Karakteristik responden berdasarkan pengetahuan perawat tentang jenis-jenis infeksi nosokomial mayoritas berkatego ri sedang yaitu 18 orang $(58,1 \%)$.

3. Karakteristik responden berdasarkan pengetahuan perawat tentang faktorfaktor terjadinya infeksi nosokomial mayoritas berkategori sedang yaitu 23 orang $(74,2 \%)$.

4. Karakteristik responden berdasarkan pengetahuan perawat tentang pertahana n terhadap infeksi nosokomial mayorita s berkategori baik yaitu 22 orang (71\%).

5. Karakteristik responden berdasarkan pengetahuan perawat tentang tanda dan gejala infeksi nosokomial mayoritas berkategori sedang yaitu 19 orang $(61,3 \%)$.

6. Karakteristik responden berdasarkan pengetahuan perawat tentang infeksi nosokomial mayoritas berkategori sedang yaitu 20 orang $(64,5 \%)$.

7. Karakteristik responden berdasarkan tindakan pencegahan infeksi nosokomia 1 mayoritas berkategori baik yaitu 19 orang $(61,3 \%)$.

8. Hasil penelitian yang dilakukan dengan menggunakan uji Rank Spearman untuk melihat hubungan pengetahuan perawat tentang infeksi nosokomial dengan tindakan pencegahannya maka diperole $\mathrm{h}$ hasil dengan nilai probabilitas $(\mathrm{p})=$ $0,011$ ( $\mathrm{p}<0,05)$ yang artinya ada hubungan dengan kekuatan hubungan $(r)=0,452$, berarti kekuatan hubungann ya cukup dan hubungan ini bersifat positif yang artinya jika pengetahuan perawat tentang infeksi nosokomial cukup maka makin cukup nilai tindakan pencegahan infeksi yang diperoleh.

\section{SARAN}

Setelah penelitian dilakukan sehingga ada beberapa saran peneliti sebagai berikut :

1. Bagi perawat di rumah sakit, hasil penelitian ini hendaknya dapat diterima sebagai bahan masukan khususnya bagi perawat yang bekerja di ruang rawat pascabedah di RS Imelda sehingga dalam pelaksanaan tindakan keperawata $\mathrm{n}$ perawat mampu memahami dan mengambil tindakan yang tepat terhadap pencegahan infeksi nosokomia 1 pada pasien-pasien pascabedah.

2. Bagi instansi pendidikan, agar menginte grasikan pembelajaran yang terkait dengan infeksi nosokomial dan tindaka 
n pencegahan infeksi nosokomial pada pasien pascabedah guna memperluas wawasan dalam pengembangan ilmu keperawatan.

3. Bagi penelitian selanjutnya, hasil penelitian ini hendaknya dapat digunak an sebagai informasi tambahan ataupun data awal untuk pengembangan penelitian selanjutnya tentang infeksi nosokomial dan tindakan pencegahan nya.

\section{DAFTAR PUSTAKA}

Arikunto, Suharsimi. (2006). Prosedur Penelitian Suatu Pendekatan Praktik, Ed. 6. Jakarta : Rineka Cipta.

Gunawan, Indra. (2006). Hubungan Tingkat Pengetahuan Perawat tentang Infeksi Nosokomial Post Operatif Appendik dengan Cara Perawatan di Ruang Rawat Inap RSU Sari Mutiara Medan. Medan : STIKes Mutiara Indonesia.

Hidayat, A.A.A., Musrifatul U. (2006). Keterampilan Dasar Praktek Klinik Kebidanan. Jakarta: Salemba Medika.

Hidayat, A.A.A., Musrifatul U. (2006). Pengantar Kebutuhan Dasar Manusia:
Aplikasi Konsep dan Proses Keperawat an Jilid 1. Jakarta: Salemba Medika.

Notoatmodjo, Soekidjo. (2003). Pendidikan dan Perilaku Kesehatan. Jakarta : Rineka Cipta.

Notoatmodjo, Soekidjo. (2005). Metodologi Penelitian Kesehatan. Jakarta: Rineka Cipta.

Nursalam. (2003). Konsep dan Penerapan Metodologi Penelitian Ilmu Keperawat an. Jakarta: Salemba Medika.

Potter, Patricia A., Perry, Anne Griffin. (2005). Buku Ajar Fundamental Kepera watan: Konsep, Proses, dan Praktik. Jakarta : EGC.

Price, Sylvia Anderson. (2005). Patofisiolog $i$ : konsep klinis proses-proses penyakit, Ed. 6. Jakarta : EGC.

Smeltzer, Suzanne C. (2001). Buku Ajar Keperawatan Medikal-Bedah Brunner \& Suddarth, Ed. 8. Jakarta : EGC.

Tietjen, L., Debora B., Noel M. (2004). Panduan Pencegahan Infeksi Untuk Fasilitas Pelayanan Kesehatan dengan Sumber Daya Terbatas. Jakarta : Yayasan Bina Pustaka Sarwono Prawir ohardjo bekerjasama dengan JNPKKR/ POGI dan JHPIEGO. 